ks. Edward Sienkiewicz

Uniwersytet Szczecinski

DOI: $10.15290 /$ std.2016.02.03

\title{
MAŁŻEŃSKIE COMMUNIO W SAKRAMENTALNYM URZECZYWISTNIENIU
}

\section{MARRIAGE COMMUNIO IN SACRAMENTAL REALIZATION}

Jesus's call raising marriage to sacramental dignity points to the inadequacy of the law within the meaning and formation of a special relationship between a man and a woman. On the other hand it does not mean its redundancy. This ratio is considered to be constitutive and results from the creation of man in God's image and His likeness. This image has not been destroyed even by a human sin that interferes with the relationship with God and between the spouses. It also has not destroyed the covenant with God of which the marriage is the image. Fulfilling this covenant in Jesus Christ, God renews the relation of a man towards a woman as well as the relationship of a man towards God .Resulting from the creation the unity of the spouses in the New Covenant shall be covered by the paschal mystery of Jesus Christ and is a real performing salvation. Beyond, the reality is open to eschatology and immersed in church as the bride of Christ forming the pattern and strengthen the covenant of marriage which is in Jesus Christ, a community of grace and the basis for understanding people.

Key words: sacrament, marriage ,creation, redemption incarnation, paschal mystery, covenant, canon law, community,person, personalism.

Zgodnie z kanonem 1055, paragraf 1. Kodeksu Prawa Kanonicznego, małżeństwo zawierane przez osoby ochrzczone zostało przez Chrystusa Pana podniesione do godności sakramentu. Natomiast w paragrafie 2. czytamy, że z tej 
samej racji między ochrzczonymi ${ }^{1}$ nie może istnieć ważna umowa małżeńska, która tym samym nie byłaby sakramentem².

Zanim pochylimy się nad sakramentalnością małżeństwa i najbardziej istotnymi jej elementami, co jest podstawowym problemem tego artykułu, może warto zdać sobie sprawę, że akurat w tej kwestii - jedności i nierozerwalności małżeństwa (kan. 1056), przed chrześcijańską wykładnią pojawia się bardzo poważne wyzwanie. Nawet jeśli nie wszyscy zawierający małżeństwa lub w jakikolwiek sposób zainteresowani tą problematyką rozumieją związek mężczyzny i kobiety tak samo, to generalnie - jeszcze do niedawna - aż tak zdecydowanie, jak ma to miejsce obecnie, małżeństwo nie było kontestowane ${ }^{3}$. I to zarówno jeśli chodzi o jego rozumienie, wynikające z tegoż konsekwencje, jak i codzienną praktykę. Nie zawsze poprzedzoną głębszą refleksją, choć często wielorako uzależnioną. Na pewno posiadającą swoje przyczyny, które są złożone i nawarstwiające się od dłuższego czasu. Nie mamy możliwości, aby przynajmniej niektóre z nich w tym miejscu wyszczególnić. Tym bardziej omówić. Niemniej mamy dziś do czynienia z bardzo poważnym kryzysem małżeństwa, na który składają się z jednej strony nietrwałość zawieranych małżeństw, a z drugiej rezygnacja $z$ ich legalizacji, a także podważanie obowiązującej formy, choćby przez sposób życia radykalnie jej zaprzeczający ${ }^{4}$. Prowadzi to do coraz częściej podejmowanych prób redefinicji związku między mężczyzną i kobietą, co trzeba uznać za przełomowy moment w naszej cywilizacji, o ile nie krytyczny. Problem jest zatem bardzo poważny. Toteż trudno sobie wyobrażać, aby w toczącą się na ten temat debatę nie włączała się chrześcijańska teologia ${ }^{5}$, której zadaniem jest wychodzenie naprzeciw zagrażającej małżeństwu praktyce i usiłującej usprawiedliwiać ją teorii.

1 Ani w pierwszym, ani w drugim paragrafie tego kanonu (1055) Kodeksu Prawa Kanonicznego nie pojawia się termin: osoba/y.

2 Kodeks Prawa Kanonicznego, przekład polski zatwierdzony przez Konferencję Episkopatu, Poznań 1984.

3 G. Koch, Sakramentologia - zbawienie przez sakramenty, tł. W. Szymona, [w:] Podręcznik teologii dogmatycznej, W. Beinert (red.), Kraków 1999, s. 333.

4 W tym ostatnim przypadku mamy na myśli związki partnerskie, także homoseksualne z przypadkami wręcz agresywnego domagania się ich legalizacji, aż po przyznanie tych samych praw, jakie mają małżeństwa. Rysującego się przez to kryzysu z pewnością nie łagodzą feministki, żądające już nie tylko większych praw dla kobiet, ale usiłujące narzucić społeczeństwu obraz rzeczywistości, w którym podsyca się niechęć, a nawet irracjonalną wrogość wobec mężczyzn.

5 Ibidem. 


\section{Cechy sakramentu małżeństwa i jego specyfika}

Przy wielkim szacunku, należnym jurydycznym uregulowaniom małżeństwa chrześcijan, problem wiary, którą trudno wykluczać jeśli chcemy mówić o kompletnym i usystematyzowanym jego obrazie, jest domeną teologii. Teologiczne kryteria właściwe są również sakramentalności małżeństwa. Tu jednak pojawiają się pewne, dość szybko narzucające się specyfikacje. I nieograniczające się tylko do kwestii szafarza oraz błogosławieństwa urzędowego świadka podczas zawierania małżeństwa zgodnie $z$ formą kanoniczną.

Przy tej okazji może warto wspomnieć o dość charakterystycznym przekonaniu - począwszy od najbardziej pierwotnych, znanych dzięki badaniom historycznym form zawierania małżeństwa - o religijnym charakterze tej rzeczywistości. Świadczą o tym liczne, obecne podczas jego zawierania we wszystkich znanych kulturach, religijne symbole. Niezależnie od przeobrażeń, jakim ulegał w historii związek między mężczyzną i kobietą, także jeśli chodzi o jego monogamiczny charakter. $Z$ tej historii nie wolno oczywiście eliminować ani tradycji starotestamentowej, decydującej o rozumieniu małżeństwa w judaizmie, ani chrześcijaństwa, odwołującego się przede wszystkim do Nowego Testamentu, rozumianego także jako korekta rozwiązań właściwych Pierwszemu Przymierzu. Nie są to jednak tradycje jedyne i najstarsze. Innymi słowy, religia czy też wiara człowieka nie jest dodatkiem tylko do ukształtowanej już rzeczywistości, którą można interpretować i rozumieć w jakikolwiek dowolny sposób, ale stanowi jej podstawę i najważniejsze kryterium rozumienia. W tym znaczeniu można mówić o tzw. sakramentach naturalnych (J. Ratzinger) związanych ze wspólnotą płci i zawieraniem małżeństwa, co umożliwiało doświadczenie religijne. Pod tym względem judaizm i chrześcijaństwo nie stanowią jakiegoś kategorialnego novum. Poza tym w przypadku tego pierwszego narzuca się dość charakterystyczne - obecne w starszych kulturach - daleko idące podporządkowanie jednostek grupie, co miało gwarantować biologiczne jej trwanie lub ciągłość pokoleniową. W tym kontekście, dostrzegalnym także w Starym Testamencie, poligamia na wczesnym etapie rozwoju, zanim pojawiło się przekonanie o wyższości moralnej małżeństwa monogamicznego, znajduje swoje wyjaśnienie. Nawet jeśli trudno jest ją z naszego punktu widzenia usprawiedliwiać, choćby ze względu na bardzo ograniczone prawa kobiet ${ }^{6}$. Nie usprawiedliwia też tego Jezus, choć wyjaśnia: „Przez wzgląd na zatwardziałość serc” (Mk 10,5) i odwołuje się czy też odsyła zwolenników listu rozwodowego do „początku”, kiedy to „Bóg stworzył ich jako mężczyznę i kobietę" (Mk 10,6), co należy traktować jako podstawę osobowej wspólnoty między jednym mężczyzną i jedną kobietą.

T. Schneider, Znaki bliskości Boga. Zarys sakramentologii, tł. J. Tyrawa, Wrocław 1995, s. 296. 
Stąd jako dość specyficzne jest w sakramencie małżeństwa jego naturalne - w znaczeniu związane z pochodzeniem człowieka; z tym wszystkim, co go kształtuje jako osobę i wyraża jako istotę - przygotowanie, które wolno traktować jako podstawę. Oczywiście nie stanowi to samo w sobie sakramentu i o sakramentalności jeszcze nie przesądza. Niemniej pominięcie tego wszystkiego w teologicznej refleksji na temat sakramentu małżeństwa byłoby brakiem wpływającym na jego rozumienie. Poza tym związanym z licznymi kryzysami, których notabene jesteśmy świadkami. Nie umniejsza to w żadnym sensie twierdzenia, że o sakramencie możemy mówić tylko w odniesieniu do przymierza małżeńskiego do Wcielenia i misterium paschalnego Jezusa Chrystusa, które sakramenty po prostu uobecniają i które określa w zasadniczym sensie rzeczywistość sakramentalną oraz związaną z nią i udzielaną łaskę. Stąd św. Paweł zaleca zawieranie małżeństwa „w Panu” (1 Kor 7,39), gdzie wspomniana „zatwardziałość serc” nie stanowi żadnego usprawiedliwienia. Małżeństwo bowiem chrześcijan w tym ujęciu nie jest już sprawą tylko doczesną, czysto naturalną, ale w misterium paschalnym Jezusa uzyskuje nowy wymiar, a chrześcijanin powinien je zawierać w duchu Jego nauki i w Jego wydarzeniu zbawczym ${ }^{7}$. Chrystusowe odesłanie do „początku” nic nie traci w tym wydarzeniu. Nie schodzi także na drugi plan. Wręcz przeciwnie. Na podstawie stworzenia - przygotowania przez Boga w ten sposób Wcielenia - małżeńska miłość w misterium zbawczym Jezusa została doprowadzona do doskonałości, ponieważ na mocy Nowego Przymierza jest objęta miłością Ojca do swojego Syna (J 17,21-23).

W Liście do Efezjan (5,21-32) Paweł pisze o „wielkiej tajemnicy-mysterion” w odniesieniu do Chrystusa i do Kościoła, przypominając wcześniej o tym, że człowiek „opuści ojca i matkę, a połączy się z żoną swoją i będą dwoje jednym ciałem" (Ef 5, 31), na które to słowa powołał się Jezus, niejako ukazując niewystarczalność samego prawa. Nie należy zatem traktować odniesienia Chrystusa do Kościoła i Kościoła do Chrystusa jako jedynie odległego, ze względu na właściwą temuż doskonałość, wzorca; tylko obrazu, który pomaga zrozumieć czym powinno być małżeństwo chrześcijan ${ }^{8}$. Chodzi tu o sakramentalną komunię,

7 J. Grześkowiak, Centralne idee teologii małżenstwa, [w:] Małżeństwo i rodzina w świetle nauki Kościoła $i$ wspótczesnej teologii, A. L. Szafrański (red.), Lublin 1985, s. 42.

8 Sobór Watykański II - ukazując Kościół jako oblubienicę Chrystusa, a małżeństwo jako sakramentalny znak tej oblubieńczej miłości - około 20 razy odwołuje się do przesłania Ef 5,22-32. Rozumienie jednak małżeńskiego przymierza tylko jako zredukowanego do samej funkcji oznaczania - odsyłania do związku Chrystusa z Kościołem, byłoby w równym stopniu redukowaniem sakramentalnej rzeczywistości, jak i samego związku Chrystusa z Kościołem, w którym wypełnia się Przymierze Boga ze swoim ludem, także ukazywane w obrazie małżeństwa. Sobór Watykański II, konstytucja dogmatyczna o Kościele Lumen gentium, p. 1. 7, [w:] idem, Konstytucje, dekrety, deklaracje, Poznań 1967; W. Necel, Matżonkowie wzmocnieni ijakby konsekrowani (kan. 1134 KPK). Szkic teologiczno-kanonicznego 
która tak jak we wspólnocie Kościoła, tak też w małżeństwie chrześcijan, jest po prostu uczestnictwem w komunii właściwej samemu Bogu ze względu na Chrystusa. Komunię - na podstawie stwórczego aktu, powołującego człowieka jako zwróconego wręcz do drugiego człowieka, aż po bliskość, jedność - pozwalającą mówić o jednym ciele. W sakramencie, którego źródłem jest misterium paschalne Jezusa, to ciało - choć zanurzone w doczesności i podlegające jej prawom - uczestniczy w ciele, o którym można mówić jako mistycznym ze względu na Chrystusa oraz ze względu na Jego całkowity i bezinteresowny dar $z$ siebie dla człowieka, co z kolei stanowi zobowiązanie do takiego samego, bezinteresownego daru mężczyzny i kobiety w związku, który tworzą w Chrystusie. Nie wolno zatem zatrzymywać się tylko na tradycyjnym rozumieniu znaku, jako czegoś zewnętrznego, jedynie odsyłającego - nawet jeśli mamy na myśli odsyłanie do nadprzyrodzonego wymiaru. W tym przypadku znak i tajemnica jest wszczepieniem relacji małżeńskiej w zbawczy czyn Boga; aktualizacją więzi Chrystusa z Kościołem w historii, w konkretnym związku małżeńskim. Tę więź i zarazem sakramentalne urzeczywistnienie Bóg przygotowuje przez rzeczywistość Pierwszego Przymierza, w którym miłość małżeńska jest obrazem miłości Boga do swojego ludu?.

Małżeństwo w tym obrazie podlega wszystkim niedoskonałościom, właściwym narodowi niezachowującemu Przymierza i okazującemu się przez to niewiernym. Niezależna od tej niewierności wierność Boga jest podstawą ekonomii Zbawienia i zrealizowania w Jezusie Chrystusie jedności oraz miłości, właściwej tylko Bogu, do której został zaproszony człowiek. W takim właśnie sensie; w rzeczywistości misterium paschalnego Jezusa, w które małżeństwo jest $z$ woli Boga włączone, można mówić o sakramentalnym znaczeniu symbolu, nie tylko odsyłającego do eschatologicznej - nadprzyrodzonej rzeczywistości, ale ją również uobecniającego. Nie oznacza to oczywiście tym samym, że ją już ostatecznie wypełnia, co właściwe jest wymiarowi chwalebnemu, do którego zmierzamy w Panu. Podobnie jak nie stanowi jeszcze zrealizowanego Królestwa Bożego zjednoczony w miłości z Chrystusem Kościół. Dlatego też wszystko, co pojawia się jako trudne w małżeństwie, nie może być inaczej rozumiane jak na sposób paschalny. Innymi słowy nawet niewierność współmałżonka nie jest wystarczającym powodem odmowy miłości i jedności, ponieważ nie odmówił jej człowiekowi Bóg ze względu na grzech - niewierność człowieka. Krzyż Chrystusa, jako cena owego braku odmowy, czyli wierności Boga Przymierzu jest też najbardziej właściwą drogą człowieka w małżeńskim przymierzu, które

komentarza w roku synodalnej refleksji nad powołaniem i misja rodziny w Kościele i świecie wspótczesnym, Pelplin 2015, s. 73.

9 Stownik małżenstwa i rodziny, E. Ozorowski (red.), Warszawa - Łomianki 1999, s. 224. 
poza miłością i jednością w Chrystusie nie znajduje ani swojej realizacji, ani nawet swojego wytłumaczenia - zrozumienia. Oblubieńcza miłość i jedność Chrystusa realizowana jest w przymierzu małżeńskim, co byłoby trudne do osiągnięcia gdyby w związku mężczyzny i kobiety miłość i jedność nie była realizowana. Przy czym w realizacji tychże małżonkowie nie są pozostawieni sami sobie, ani ograniczeni jedynie do swoich naturalnych zdolności, co nie oznacza tym samym zwolnienia $z$ wysiłku, a nawet trudu w tym względzie. Otrzymują bowiem w sakramencie małżeństwa od Chrystusa właściwą im łaskę, przeznaczoną do udoskonalania ich miłości i umocnienia nierozerwalnej jedności w warunkach ogłoszonego przez Jezusa Królestwa Bożego ${ }^{10}$, które staje się dla nich podstawowym wyznacznikiem rozumienia swojego związku i jego realizacji w świecie.

W teologicznej debacie na temat małżeństwa co pewien czas odżywa kwestia łaski Bożej w małżeństwach niesakramentalnych. Nie zagłębiając się w szczegóły, na podstawie których Karl Rahner twierdzi, że małżeństwo staje się wydarzeniem łaski nie dopiero wtedy, kiedy staje się sakramentem, lecz wydarzenie łaski małżeństwa staje się po prostu sakramentalnym przejawem łaski jako opus operatum w kościelnym małżeństwie ochrzczonych ${ }^{11}$, w tej problematyce powinniśmy się cofnąć do czegoś wcześniejszego; do argumentów wynikających ze stworzenia, co wyraża określenie: „na początku” ${ }^{12}$. Theodor Schneider z kolei, snując refleksję na temat sakramentalności małżeństwa i zastanawiając się nad treścią przywołanego powyżej kanonu $1055 \mathrm{KPK}$, czemu przyświeca pragnienie przezwyciężenia pewnej zewnętrzności w wydarzeniu sakramentalnym, pisze: „Dla ochrzczonych chrześcijan rzeczywistość stworzenia jest bezpośrednio i równocześnie sakramentem, życiowym spełnieniem się w Kościele Jezusa Chrystusa, w którym On sam jest obecny i działa"13. Obecne są tu trzy elementy: stworzenie, rzeczywistość Kościoła i eschatologiczne otwarcie. Szczególna troska Kościoła, odnosząca się do małżeństwa, powołuje się na owo podniesienie tegoż do godności sakramentu przez Chrystusa, który nie ustanowił jakiegoś osobnego znaku sakramentalnego, ale wprost odsyła do „początku”, niejako akceptując je takim, jakim wyszło z Bożej ręki ${ }^{14}$. Benedetto Testa, przy okazji omawiania problemu szafarzy sakramentu małżeństwa, jako podstawę łaski sakramentalnej i warunkującej ją umowy małżeńskiej, ukazuje

$10 \quad$ Ibidem, s. 416.

11 K. Rahner, Die Ehe als Sakrament, [w:] Karl Rahner, Schriften zur Theologie, Bd. 8, Einsiedeln - Benziger, 1967, s. 275.

12 J. Grześkowiak, Centralne idee teologii matżeństwa, op. cit., s. 45-46.

13 T. Schneider, Znaki bliskości Boga. Zarys sakramentologii, op. cit., s. 319.

14 J. Grześkowiak, Centralne idee teologii malżeństwa, op. cit., s. 68. 
wzajemne oddanie się sobie i zarazem całkowite przyjęcie siebie jako osób ${ }^{15}$. Pochylenie się zatem nad konstytutywnymi kwestiami dotyczącymi osoby ludzkiej wydaje się tu nie do pominięcia. Oczywiście jeśli myślimy o przezwyciężeniu kłopotliwej jednostronności.

Dlatego też poza wszystkimi ważnymi elementami w sakramentalnej rzeczywistości bardzo istotne jest ukazanie najgłębszych podstaw wzajemnych relacji mężczyzny i kobiety, czyli ontologicznych. W Jezusie Chrystusie spontaniczna i naturalna, wynikająca ze stworzenia ( $z$ owego „początku”) miłość, staje się wydarzeniem sakramentalnym. Chodzi więc o właściwe uświęcenie rzeczywistości sakramentalnej - czyli włączenie w nadprzyrodzony porządek Zbawienia antropologicznej istoty małżeństwa.

\section{Jurydyczna niewystarczalność}

Zanim jednak zajmiemy się problemem „początku” może warto zauważyć, że w kontekście powyższych rozważań, przyjęta w prawie kanonicznym zasada „automatycznej sakramentalności”, budzi tyleż samo dyskusji, co poczucia niewystarczalności. Na pewno jednostronności, na której nie wolno się zatrzymać. Choćby ze względu na wyzwania, jakie pojawiają się przed teologią małżeństwa w postaci współczesnych kryzysów. Jeśli małżeństwo w rozumieniu prawa kanonicznego „tworzy” wola małżonków, to wszelkie jej błędne rozumienie musi rzutować na obraz samego małżeństwa. Nie chodzi nam o podważanie tej zasady, ani osłabianie. Chodzi o to, że największe problemy z wolą ludzką; $z$ jej pojmowaniem i działaniem, pojawiają się tam, gdzie odrywa się ją od rzeczywistości i struktury ludzkiej osoby. Jak bowiem można rozumieć wolę, jej działanie, kiedy nie rozumie się człowieka - osoby ${ }^{16}$. Grześkowiak pisał wiele lat temu: „Małżeństwo już samo w sobie ma głęboki wymiar teologiczny, zanim jeszcze stanie się pełnym sakramentem. Myśl jakoby dopiero umowa prawna sprawiała to wszystko, co ma stanowić nasyconą miłością treść sakramentalnego życia małżeńskiego, byłaby niczym innym jak zwyczajnym podpisywaniem się pod pewnego rodzaju chrześcijańską magią"17.

Jak się wydaje przezwyciężenie tej „magii”, której istnienie i to w szerokiej skali wśród nupturientów potwierdza wielu duszpasterzy, jest bardzo zbieżne z przezwyciężeniem dotykającego dziś małżeństwo głębokiego kryzysu. Powodzenia bowiem chrześcijańskiego małżeństwa nie gwarantuje samo przez się kościelne prawodawstwo, podobnie jak państwowe. Nie chodzi nam w tym

15 B. Testa, Sakramenty Kościoła, tł. L. Balter, Poznań 1998, s. 355.

16 C.S. Bartnik, Spotkaniepersonalistyczne, [w:] Kumądrościteologii, K. Góźdź, E. Sienkiewicz (red.), Szczecin 2008, s. 385-391.

17 J. Grześkowiak, Centralne idee teologii matżeństwa, op. cit., s. 48. 
miejscu o pomniejszanie, a tym bardziej deprecjonowanie tegoż. Ale o zwrócenie uwagi na niewystarczalność w tym względzie, który decyduje o pełnym rozumieniu tej rzeczywistości i przede wszystkim pełnej realizacji jednego oraz nierozerwalnego związku. I tu konieczna jest chrześcijańska wiara oraz miłość, co bez wątpienia jest domeną teologii. Poza tym wspomniany kryzys małżeństwa i jego praktyka uwarunkowane są nie tylko przez wpływy zewnętrzne, spowodowane sekularyzacją, ale również przez przyczyny wewnątrzkościelne ${ }^{18}$. A tu musi się pojawić kwestia odpowiedzialności, głębokiej refleksji na temat sposobów i owoców misji głoszenia Dobrej Nowiny, kerygmatycznego zaangażowania, czego same jurydyczne procedury nie załatwią. Zwłaszcza w atmosferze charakterystycznej, właściwej ponowoczesności mentalności, w której każde prawo pojmuje się jako ograniczenie w dążeniu człowieka do szczęścia, a nie zabezpieczenie, aby temu dążeniu jak najmniej stawało na drodze. Z całą pewnością nawet najbardziej sumiennie potraktowane przygotowanie bliższe do małżeństwa tego nie rozwiąże. Szczególnie w przypadku osób o słabej wierze, pozbawionych $-z$ różnych względów - doświadczenia wspólnoty religijnej we własnej parafii, często z powodu nieobecności w niej, zwłaszcza na Eucharystii. Do tego - co jest dziś dość częstym przypadkiem - pozbawionych prawdziwej wspólnoty rodzinnego domu; miłości, bezpieczeństwa i gruntownego wychowania. Nie mają one specjalnych predyspozycji do stworzenia trwałej, opartej na miłości wspólnoty małżeńskiej, w której krzyż, zdolność do wyrzeczenia i ofiary, do całkowitego daru z siebie, Chrystus ukazuje jako najbardziej właściwą drogę do urzeczywistnienia sakramentalnej łaski.

Podkreślmy to jeszcze raz. Nie chodzi o deprecjonowanie kościelnego prawa ani nawet o osłabianie w jakimkolwiek sensie jego skuteczności. Chodzi właśnie o jego wzmocnienie. Przywrócenie temuż jego autorytetu przez właściwe rozumienie i uporządkowanie tego wszystkiego, co od prawa już nie zależy, ale nieuporządkowane może wpływać na niewłaściwe jego rozumienie, stając się punktem wyjścia do naginania prawa lub poszukiwania w nim różnych furtek. Okazuje się również powodem jego niewystarczalności czy też nieskuteczności. Chodzi wreszcie o korektę, jakiej dokonywał Jezus nie roszcząc sobie pretensji do zniesienia prawa, uchylenia go w czymkolwiek ważnym dla człowieka i jego zbawienia, wyraźnie jednak piętnując, wynikające z niewłaściwego rozumienia prawa, nadużycia. Otwierając przy tym człowieka na działanie Ducha Bożego, który nie może być w żadnym sensie rozumiany jako konkurencja, czy choćby ograniczenie prawa. I tu niezbędna jest kerygma, świadome dalsze przygotowanie do małżeństwa, aby przez wewnętrzną przemianę, czyli nawrócenie, właściwie rozumieć prawo; jego skuteczność. Niezbędna jest przede wszystkim 
miłość, która jeśli będzie niewystarczająca nie zostanie zrekompensowana nawet przez najlepsze prawo. Kiedy jednak będzie otwieraniem się na miłość Boga do człowieka, także w małżeństwie, na pewno nie doprowadzi do jakiegokolwiek konfliktu z prawem; nie będzie też przez nie w jakikolwiek sposób krępowana.

Wyłania się tu problem, który wciąż - mimo dość wyraźnej propozycji oraz wysiłku chrześcijańskiej teologii - kładzie się cieniem na wielu wymiarach naszego życia, także małżeńskiego. Mamy tu na myśli najbardziej rozpowszechniony (jeśli w ogóle wolno tak mówić w stanie obecnej wielości i różnorodności stanowisk oraz opinii, nie wyłączając z nich także tych - jak się je określa naukowych) obraz człowieka; sposób jego rozumienia, który utrudnia dotarcie do wewnętrznej struktury osobowej. Podstawowego wymiaru dokonującej się wymiany - wzajemnego obdarowania, pozwalającego mówić o tym, że małżonkowie stają się ,jednym ciałem” przez bezinteresowny dar z siebie, wyrażający się w communio, do którego uzdalnia człowieka Bóg w akcie stworzenia i który umacnia oraz uświęca w sakramencie małżeństwa. Świadomość, a zwłaszcza doświadczenie takiej relacji nie są możliwe bez uświadomienia sobie oraz przeżywania własnej podmiotowości; złożonej, wewnętrznej struktury osobowej. Jezus Chrystus w swoim odwołaniu się do początku, nie pozwalając w rozmowie z faryzeuszami zatrzymać się tylko na kwestiach prawnych (nie dając się w nie wciągnąć), odsyła do początku. To znaczy wskazuje, że Bóg wymaga od człowieka tego, do czego go uzdolnił; przez swoje stworzenie go takim właśnie - realizującym się w pełni przez osobową jedność z drugim człowiekiem - przygotował. To stworzenie i przygotowanie zostało sakramentalnie wzmocnione i wyniesione przez Jezusa Chrystusa, który stając się w misterium paschalnym bezinteresownym darem nie uczynił tego obok człowieka, ale przez Wcielenie, otwierając jednocześnie ludzką strukturę osobową na dar, jakim jest sam Bóg, zjednoczony z ludzką naturą w Boskiej Osobie. Otwarcie to, przez Wcielenie i misterium paschalne, realizowane jest w objawionej człowiekowi tajemnicy wewnętrznego życia Bożego, do której też człowiek - nie w samotności jak i Bóg nie jest samotny - został wezwany.

\section{O jaki początek chodzi?}

Objawienie Trójcy Świętej następuje w czasie. Ale też w czasie, w historii, ukazuje się Wcielone Słowo, najpełniej objawiające Boga jako osobową jedność i miłość. Niemniej już przez sam akt stworzenia człowieka jako mężczyzny i kobiety w ich wzajemnej relacji, Stwórca ukazuje kim jest; jaka jest Jego istota i jaka, ze względu na Niego - na akt stworzenia, pochodzenia człowieka z ręki Boga - jest istota bytu ludzkiego. Wróćmy zatem do owego „początku”, o którym mówi Jezus. Na pewno nie chodzi tu o początek w postaci pisemnej relacji 
o dokonywanym przez Boga stworzeniu świata i człowieka ${ }^{19}$, ale o Tradycję powstałą na podstawie doświadczenia Boga wyzwalającego swój naród, troszczącego się o lud, z którym zawiera Przymierze i pozwala się osiedlić w Ziemi Obiecanej ${ }^{20}$. W tej ziemi zawierane są małżeństwa, stanowiące obraz relacji Boga do narodu, zarówno dobrych jak i złych; obraz błogosławieństwa i grzechu, jak ukazują to prorocy (Iz 1,21-23; 62,4-5; Jr 2,2; 3,1-4; Oz 1,3) ${ }^{21}$. Wyczulony na to doświadczenie Autor natchniony dostrzega nierówną - niewłaściwą pozycję kobiety w relacji do mężczyzny, co wiąże się z napiętnowaną przez Jezusa „zatwardziałością serca”22. I z takiej perspektywy pisze swój tekst, odwołując się do początku. To znaczy, chcąc ukazać najbardziej pierwotny, podstawowy wymiar w człowieku ze względu na stwórcze działanie Boga, wykluczające tego rodzaju, nawet jeśli sankcjonowaną źle rozumianym prawem, nierówność.

Zawarte w tym opisie słowa: „Nie jest dobrze, aby ten człowiek (Adam) był sam, chcę uczynić dla niego odpowiednią pomoc" $(\operatorname{Rdz} 2,18)^{23}$, świadczą o tym, że chodzi tu o coś bardzo istotnego dla człowieka, dzięki czemu mógłby on w pełni egzystować, czyli spełniać się jako osoba ${ }^{24}$. Chodzi o podobieństwo osobowościowe; zaradzenie samotności człowieka i partnerstwo intelektualne ${ }^{25}$. W celu zaradzenia temu „brakowi” Bóg sprowadza na człowieka sen ${ }^{26}$ i bierze jeden $z$ jego boków (lub jedno $z$ jego żeber) oraz buduje (dosłownie - bānâ)

$19 \quad$ B. Jacob, Das Buch Genesis, Stuttgart 2000, s. 15.

20 J. L. Ska, La structure du Pentateuque dans sa forme canonique, „Zeitschrift für die alttestamentliche Wissenschaft" 113 (2001), s. 330-352; F. Garcia López, Il Pentateuco, Brescia 2004, s. 266-270; J. Lemański, Księga Rodzaju. Rozdziały 1-11, [w:] Nowy komentarz biblijny - Stary Testament, A. Paciorek, R. Bartnicki, A. Tronina (red.), Częstochowa 2013, s. 38-40.

21 Stary Testament, poszukując najbardziej odpowiednich obrazów miłości Boga do człowieka, wskazuje na postać oblubienicy - małżonki. Odwołując się do tej symboliki, autorzy biblijni określają małżeństwo jako przymierze, a Przymierze z Bogiem nazywają wprost małżeństwem (Ml 2,14). Izajasz, Jeremiasz i Ozeasz ukazują małżeństwo jako wybraną przez Boga drogę do objawienia Przymierza Boga z ludźmi. A. Sarmiento, Matżeństwo chrześcijańskie. Podręcznik teologii malżeństwa i rodziny, Kraków 2002, s. 19.

22 T. Schneider, Znaki bliskości Boga, op. cit., s. 323.

23 „Nie jest dobrze” znaczy w tym miejscu, że nawet Bóg nie jest dla człowieka odpowiednią pomocą. Podobnie jak stworzone przez Boga zwierzęta. The Dictionary of Classical Hebrew, t. 1-6, D. J. A. Clines (red.), Sheffield 1993-2007, s. 604; Epos o Gilgameszu, tł. K. Łyczkowska, Warszawa 2002, s. 5-9. J. Lemański, Księga Rodzaju. Rozdziaty 1-11, [w:] Nowy komentarz biblijny, op. cit., s. 233.

25 Ibidem, s. 234.

26 Chodzi o szczególny rodzaj snu, występujący w momentach zwrotnych ( $\operatorname{Rdz} 5$,12; Jon 1,5; $1 \mathrm{Sm}$ 26,12). Bóg zsyła na człowieka taki sen, aby nie przeszkadzał Mu w działaniu, albo aby mógł się komuś objawić w szczególny sposób. J. Lemański, Księga Rodzaju. Rozdziały 1-11, op. cit., s. 235. 
z niego niewiastę 27 . Kiedy Bóg przyprowadza niewiastę do Adama ten mówi: „ta przynajmniej/w końcu jest kością z moich kości i ciałem z mego ciała (w. 23a) ${ }^{28}$. Okrzyk ten wyraża najwyższą akceptację w rodzinie - formuła pokrewieństwa. Autor natchniony wyraża dzięki tej grze słów identyczność natury i zarazem różnicę płci. Trzeba tu mówić o wyjątkowej więzi, przewyższającej więzy krwi i pozwalającej niejako ponownie stać się jednym ciałem. Autor chcąc to jeszcze wzmocnić pisze, że mężczyzna opuszcza swoich rodziców. Nawiązanie do tego znajdujemy w księdze Pieśni nad Pieśniami $(1,6 \mathrm{~b})$, gdzie zawarte jest pragnienie prokreacji i nadzieja nieśmiertelności (Pnp 8,6-7), dzięki potężnej miłości obojga. Jakby chodziło o podkreślenie, że aby cieszyć się urokami przygotowanego przez Boga człowiekowi ogrodu należy dzielić swoje uczucia z drugą osobą ${ }^{29}$.

Opowiadanie zawierające bogatą symbolikę ukazuje Boga jako stwarzającego człowieka na swój obraz i swoje podobieństwo ( $\mathrm{Rd} z 1,26-27)$, który to obraz zawiera mężczyznę i kobietę oraz jednoczącą ich i uzupełniającą nawzajem miłość oblubieńczą ${ }^{30}$. Dlatego też jedność i nierozerwalność wspólnoty małżeńskiej nie mogą być traktowane jako pewna ewentualność pośród wielu innych lub jakiś stan doskonałości, który jest wprawdzie aktualny, wyznaczony jako wzór, ale nie przez wszystkich możliwy do osiągnięcia. Zarówno jedność jak i nierozerwalność małżeństwa ze względu na samego Boga i sposób stworzenia przez Niego człowieka są strukturalnym i nieodzownym elementem każdego przymierza małżeńskiego. $\mathrm{Z}$ tego samego powodu ostatecznym kryterium rozumienia małżeństwa (jego istoty) i relacji miłości między małżonkami jest objawiający się człowiekowi Bóg i zarazem człowiek w swojej strukturze bytowej, to znaczy tak, jak został przez Boga stworzony - powołany do istnienia, w jaki sposób „wyszedł z Jego ręki” "31; określającej w nim to, co jest istotne,

27 Bóg nazwany jest tu „budowniczym” z bardzo wyraźną analogią do budowy świątyni (1 Kor 3,16), najważniejszego jej elementu, czyli „kamienia węgielnego”, gwarantującego jej stabilność. Theological Dictionary of the Old Testament, G. J. Botterweck, H. Ringgren, H. J. Fabry (red.), Grand Rapids - Cambridge 1977-2006, s. 400-405.

28 Samotność mężczyzny zakończyła się dopiero po stworzeniu Ewy: „ta dopiero jest kością z moich kości i ciałem z mego ciała” (Rdz 2,23). Jego inność („osobność”) od zwierząt wypływała z tego, że wśród nich tylko on był osobą. Dopiero osobowa godność Ewy zakończyła samotność, umożliwiła Adamowi odnalezienie siebie i stworzenie pierwszego związku małżeńskiego ( $\mathrm{Rdz} 2$ 2,24). J. Kupczak, Teologiczna semantyka płci, Kraków 2013, s. $46-48$.

29 J. Lemański, Księga Rodzaju. Rozdziały 1-11, op. cit., s. 237.

30 Kodeks Prawa Kanonicznego, kan. 1056; Jan Paweł II, Zwiazek między pierwotna niewinnościa a odkupieniem dokonanym przez Chrystusa (katecheza z dn. 26.09.1978), [w:] Jan Paweł II, Dzieła zebrane, t. VI, Kraków 2007, s. 97-99; W. Necel, Matżonkowie wzmocnieni i jakby konsekrowani (kan. 1134 KPK)..., op. cit., s. 74-75.

31 Sobór Watykański II, Lumen gentium, p. 48. 
niezbywalne, konstytutywne, ponieważ przewyższające wszelkie inne relacje, nawet między najbliższymi ${ }^{32}$. Dlatego o małżeństwie, poprzez ową istotną w nim relację miłości, realizującej się w jedności i nierozerwalności, należy mówić jako wpisanym w naturę człowieka ${ }^{33}$.

Szczególną relację mężczyzny i kobiety, choć negatywnie, ukazuje także opowiadanie o upadku - o grzechu. Mimo że wąż, posiadający bogatą symbolikę, atakuje niewiastę, która „wzięła owoc z zakazanego drzewa i zjadła”, to dała ona także owoc swojemu mężowi, który z nią był i on również zjadł (Rdz 3,6b). Mężczyzna nie jest więc tylko świadkiem całego zajścia, ale ponosi taką samą odpowiedzialność jak niewiasta, która nie musi go jakoś szczególnie namawiać do zjedzenia owocu ${ }^{34}$. Po jego spożyciu oboje dostrzegają, że są nadzy, co im wcześniej nie przeszkadzało. Sporządzają sobie okrycia z liści figowca. Opis mówi o rozbiciu tożsamości i utracie pierwotnej jedności między tymi, którzy mieli stanowić jedno ciało ( $\mathrm{Rd} z 2$ 2,24-25). Zmienia się również ich relacja do Boga (ukrywają się przed Nim) i zaczynają się obwiniać ${ }^{35}$. Stan pierwotnej harmonii zajmuje nieporządek. Dotychczasowa natura człowieka została zraniona ${ }^{36}$. Kobieta będzie musiała liczyć się z bólem związanym z porodami i z podporządkowaniem mężczyźnie, a ten będzie nad nią panował ${ }^{37}$. Ciekawa jest interpretacja kierowanych w stronę mężczyzny „pragnień” kobiety. To ten sam termin - niezwykle rzadki w Biblii - który określa jej pragnienie zakazanego owocu. Pragnienia są zatem określone jako prowadzące do grzechu, zniszczenia prawidłowych relacji małżeńskich ${ }^{38}$.

Podsumowując powyższe, można sądzić, że przyczyny głębokiego kryzysu małżeństwa w naszych czasach, znajdują swoją zapowiedź i zarazem wyjaśnienie

32 „Dlatego opuści człowiek ojca i matkę, a połączy się z żoną swoją, i będą dwoje jednym ciałem” (Ef 5,31). W. Necel, Matzonkowie wzmocnieni i jakby konsekrowani (kan. 1134 KPK)..., op. cit., s. 82.

33 Stownik matżeństwa i rodziny, op. cit., s. 415.

34 Z. Pawłowski, Opowiadanie, Bógipoczatek. Teologia narracyjna Rdz 1-3, „Rozprawy i Studia Biblijne" 13, Warszawa 2003, s. 398.

35 M. Sternberg, The Poetics of Biblical Narrative. Ideological Literature and the Drama of Reading, Bloomington 1987, s. 176-179.

36 J. Lemański, Księga Rodzaju. Rozdziaty 1-11, op. cit., s. 251.

37 A. Schüle, Der Prolog der hebräischen Bibel. Der literar und theologiegeschichtliche Diskurs der Urgeschichte (Genesis I - II), Zürich 2006, s. 79.

38 B. T. Arnold, J. H. Choi, A Guide to Biblical Hebrew Syntax, Cambridge 2003, s. 69;

H. Ch. Brichto, The Names of God, New York 1998, s. 90. 
już na pierwszych kartach Pisma Świętego ${ }^{39}$. Człowiek oddalając się od Boga przez grzech wprowadził również nieporządek w relację mężczyzny do kobiety ${ }^{40}$. W ten sposób została naruszona istota małżeńskiej wspólnoty, której najbardziej zagraża egoizm i chęć panowania mężczyzny nad kobietą ( $\operatorname{Rdz} 3,10-18)$. Ale na początku dziejów pojawia się również zapowiedź, że nawet najbardziej głęboki kryzys małżeństwa może być w tej samej wspólnocie przezwyciężony, ponieważ Bóg dochowuje wierności swojemu Przymierzu, którego obrazem jest przymierze między mężczyzną i kobietą ${ }^{41}$.

\section{Wcielenie i misterium paschalne Jezusa pełnym objawieniem oraz urzeczywistnieniem komunii małżonków}

Czy dochowanie Przymierza przez Boga, prowadzące do Nowego Przymierza we krwi Jezusa, wprowadza jakieś istotne, nowe elementy do przymierza małżeńskiego? Co zmienia się w rzeczywistości małżeństwa dzięki Wcieleniu i misterium paschalnemu Jezusa, podnoszącego małżeństwo do godności sakramentu? Wspomniana jedność i nierozerwalność oraz będąca ich podstawą miłość, pochodząca z nieogarnionej miłości Boga stwarzającego mężczyznę i kobietę, należy - jak to określono powyżej - do natury małżeństwa. Ponieważ przymierze małżeńskie jest istotowo wplecione w stworzenie człowieka (mężczyzny i kobiety), pojawiająca się w naturze wyraźna rysa, pęknięcie z powodu grzechu, dotyczy także małżeństwa. Ale jak grzech człowieka nie znosi całkowicie istnienia przymierza, jego cią̧łej aktualności, mimo niewierności jednej ze stron (człowieka), tak też małżeństwo nie przestaje być obrazem Przymierza Boga z człowiekiem. Dlatego wszystko, co decyduje o nowej sytuacji Przymierza Boga i człowieka po Wcieleniu Jezusa Chrystusa, decyduje również o nowej sytuacji małżeństwa, któremu nic z istotnych elementów się nie dodaje, ani nie zmienia, ale w Jezusie Chrystusie jest ono bardziej zjednoczone z Bogiem, co nie tylko zakłada bardziej obecny w małżeństwie wymiar eschatologiczny lecz również, ze względu na to, głębsze relacje między małżonkami ${ }^{42}$. Chodzi tu o intensywność tych relacji, komunię dowartościowaną przez bezinteresowny dar Boga w Jezusie Chrystusie. Mówiąc o „wspaniałym dziele stworzenia

39 Jan Paweł II, List do Rodzin, Rzym 1994, p. 6. E. Ozorowski, Malzeństwo w historii zbawienia, [w:] Stownik matżeństwa i rodziny, op. cit., s. 225; A. Sarmiento, Matżeństwo chrześcijańskie..., op. cit., Kraków 2002, s. 63-69.

$40 \quad$ K. Romaniuk, Matżeństwo i rodzina wedtug Biblii, Warszawa 1994, s. 65-74.

41 R. Bartnicki, Poglady na matżeństwo w początkach ery chrześcijańskiej, [w:] Rodzina droga Kościoła, Księga Jubileuszowa na 25-leciepostugipasterskiej Biskupa Łomżyńskiego Stanisława Stefanka, M. Ozorowski, W. Nowacki (red.), Łomża 2005, s. 293-294.

42 W. Necel, Matżonkowie wzmocnieni i jakby konsekrowani (kan. 1134 KPK)..., op. cit., s. 70. 
świata i jeszcze wspanialszym dziele Zbawienia”43, możemy mieć na myśli także „wspanialszą" rzeczywistość małżeństwa, ze względu na Wcielenie i misterium paschalne Jezusa Chrystusa. Wypływająca stąd łaska sakramentalna posiada charakter uzdrawiający, przezwyciężając związany z grzechem egoizm, zamykanie się w sobie, szukanie własnych przyjemności i pomagając otwierać się na drugiego człowieka, na wzajemną pomoc ${ }^{44}$.

Bóg stwarzając człowieka niejako nakierowuje go na Boską tajemnicę, czyniąc jednocześnie byt ludzki zdolny do dialogu z Bogiem ${ }^{45}$. Mimo to z powodu złego wyboru człowieka Księga Rodzaju ukazuje cień bezbożności i zamknięcie się na Boga, który chcąc ratować ludzi zawiera z nimi Przymierze. Wypełnia się ono w Jezusie Chrystusie, wprowadzającym w swoim misterium paschalnym ludzkość w nowe odniesienie do Boga, włączające człowieka do Zbawienia i przywracające go samemu sobie ${ }^{46}$. Uzdrowienie to i przezwyciężenie jest „na miarę” osobowego samoudzielania się człowiekowi w Jezusie Chrystusie Boga. Uzdalnia ono małżonków do odkrywania i przeżywania swojej wspólnej i indywidualnej komunii z Bogiem ${ }^{47}$. Niemniej zarówno rozumienie jak i doświadczanie takiego charakteru wzajemnej relacji, uwarunkowane jest wprost odpowiedzią człowieka objawiającemu się i będącemu bezinteresownym darem z siebie Bogu, czyli odczytaniem, także w małżeństwie, powołania i dążeniem do świętości ${ }^{4}$.

Jak już wspominaliśmy o tym powyżej, człowiek został stworzony na obraz Boży i jako do Boga podobny (Rdz 1,26-27). Nie ze względu na jakiś jeden, choćby najważniejszy element jego bytu, np. duchowy. Chodzi o całego człowieka w jego współistnieniu, szczególnej relacji do drugiego człowieka - mężczyzny

$43 \quad$ Konferencja Episkopatu Polski, Mszat Rzymski dla diecezji polskich, Warszawa 1986, s. 168.

44 Katechizm Kościoła Katolickiego 1609; Stownik małżenstwa i rodziny, op. cit., s. 415.

45 C. Valverde, Antropologia filozoficzna, Poznań 1998, 377-383; A. A. Napiórkowski, Misterium communionis. Eklezjalny paradygmat dziejów zbawienia, Kraków 2006, 29-33, 46-50; M. Jagodziński, Antropologiczno-komunikacyjne podstawy sakramentów, „Studia Diecezji Radomskiej” t. VI, Radom 2004, 247-255, s. 251.

J. Auer, Die Sakramente der Kirche, Regensburg 1972, s. 219; „Otwarcie się na całość, na nieskończoność, czyni człowieka. Człowiek przez to jest człowiekiem i przez to sięga nieskończenie wyżej poza siebie, tym bardziej jest człowiekiem, im mniej jest w sobie zamknięty, «ograniczony». Ten jest jednak - powiedzmy to raz jeszcze - najbardziej człowiekiem, kto jest najbardziej nieograniczony, kto z tym, co nieskończone - z samą Nieskończonością! - nie tylko wchodzi w kontakt, lecz stanowi z nią jedność: Jezus Chrystus. W Nim uczłowieczenie doszło rzeczywiście do swego kresu”. J. Ratzinger, Wprowadzenie w chrześcijaństwo, tł. Z. Włodkowa, Kraków 1994, s. 227-235.

47 K. Lubowicki, Duchowość matzeńska wnauczaniu Jana Pawła II, Kraków 2005, s. 228-272.

48 W. Necel, Matzonkowie wzmocnieni i jakby konsekrowani (kan. 1134 KPK)..., op. cit., s. 69. 
i kobiety ${ }^{49}$. Zrozumienie tej prawdy zwiększa się dzięki tradycji Nowego Testamentu, w którym, w Jezusie Chrystusie, została objawiona tajemnica dotycząca wewnętrznego życia Bożego. Przypomina nam ona, że zostaliśmy stworzeni na obraz Bożej komunii. Człowiek zatem bez Trójjedynego Boga nie tylko nie może się zrealizować ani dostąpić Zbawienia ${ }^{50}$, ale bez tej objawionej prawdy nie rozumie swojej istoty, natury własnego bytu, do której należy szczególna relacja mężczyzny do kobiety. Objawiona tajemnica Trójcy Świętej jest bowiem wzorem i źródłem małżeństwa w komunijnym wymiarze życia ${ }^{51}$. Trójjedyny Bóg, powołując człowieka do istnienia na swoje podobieństwo, nie tylko dzieli się z nim możliwością przekazywania życia, ale uzdalnia człowieka do tworzenia prawdziwej wspólnoty, na wzór tej doskonałej, która zachodzi między Osobami Bożymi $^{52}$, aby każde nowe życie już w momencie poczęcia i przyjścia na świat było obrazem Wspólnoty, w której wieczne uczestnictwo jest naszym przeznaczeniem. Małżeństwo od samego początku znajduje się w zbawczych planach Bożych ${ }^{53}$, do których należy również włączenie go w komunię właściwą Synowi, znajdującemu się w relacji miłości do Ojca w Duchu Świętym ${ }^{54}$.

W Jezusie Chrystusie, zawierającym Nowe Przymierze przez misterium paschalne, małżeństwo w perspektywie ogłoszonego przez Jezusa Królestwa Bożego uzyskuje niejako swoją nową jakość i tym samym nowe zadanie ${ }^{55}$. Drogą do jego realizacji, w myśl św. Pawła, jest Kościół jako Oblubienica Chrystusa (Ef 5,22-24) ${ }^{56}$. W związku z tym małżeństwo jest uczestnictwem w oblubieńczym przymierzu Chrystusa i Kościoła, w zbawczym działaniu ${ }^{57}$, a także stanowi uobecnienie zbawczej miłości Chrystusa do Kościoła. Małżeństwo, które w Eden stało się środowiskiem grzechu i śmierci, we wspólnocie Maryi i Józefa

49 T. Schneider, Znaki bliskości Boga, op. cit., s. 309.

$50 \quad$ Franciszek, Evangelii gaudium, Rzym 2013, 178.

51 S. Stefanek, Rodzina-komunia osób, [w:] Stownik matżeństwa i rodziny, op. cit., s. 388-389.

52 J. S. Szymczak, Sakrament małżeństwa drogą wzrostu Kościoła, Łomianki 2001, s. 77-88.

53 Katechizm Kościoła Katolickiego, Poznań 1994, p. 2203.

54 Jan Paweł II, Mężczyzna i niewiasta stworzyt ich. Odkupienie ciała a sakramentalność matzeństwa, T. Styczeń (red.), Lublin 2008, 33. J. D. Szczurek, Trójjedyny. Traktat o Bogu w Trójcy Świętej, Kraków 2003, s. 214n.; S. Kunka, Teologiczna wizja cielesności człowieka w nauczaniu Karola Wojtyty - Jana Pawła II, Lublin 2012, 62-65.

55 J. Grześkowiak, Misterium matżeństwa. Sakrament matżeństwa jako symbol przymierza Boga z ludźmi, Poznań 1993; M. Ozorowski, Matżeństwo. Przymierze Bosko-ludzkie, [w:] Stownik matżenstwa i rodziny, op. cit., s. 224-225.

56 Katechizm Kościoła Katolickiego, p. 796.

57 Jan Paweł II, Familiaris consortio, Watykan 1981, 13. 20. 38. 49. 51; Katechizm Kościoła Katolickiego 1639; R. Skrzypczak, Kościót jako Niewiasta w relacji do Chrystusa swego Oblubieńca, Warszawa 2001, s. 85-100. 
(Łk 11,34) staje się środowiskiem łaski i życia ${ }^{58}$. Założony przez Jezusa Kościół jako wspólnota, w Nowym Przymierzu nie tylko jest fundamentem przymierza między mężczyzną i kobietą, tworzących przez to prawdziwą komunię osób, ale też tę osobową wspólnotę pozwala rozumieć jako obraz miłości oraz wspólnoty, jaka pojawia się między Jezusem a Jego Kościołem ${ }^{59}$.

\section{Rzetelna antropologia potrzebuje rzetelnej teologii ludzkiej osoby}

Powyższe refleksje upoważniają nas do stwierdzenia, że człowiek tak został stworzony przez Boga, że mężczyzna i kobieta; w szczególnej, zachodzącej między nimi relacji, stają się w pełni sobą. Postępujący rozwój teologii małżeństwa, choć relacjonowany z perspektywy Przymierza - podobnie zresztą jak samo opowiadanie o początkach - nie pozostawia żadnych wątpliwości co do fundamentalnego charakteru tej relacji, określającego również relację Boga do człowieka w stworzeniu i Odkupieniu. Już samo to każe poddawać krytyce wszelkie próby separowania stworzenia i Odkupienia, także w kontekście małżeństwa. Co więcej, relacja ta uchyla nieco tajemnicę okrywającą istotę samego Boga, aby byt ludzki, starając się przez trud zrozumienia swojej wiary, mógł odpowiadać na pytanie: kim jest Bóg? Poza tym pogłębiał swoją odpowiedź na ciągle aktualne pytanie: kim jest człowiek? Nasze dotychczasowe rozważania pozwalają na opinię, zgodnie z którą odpowiedź na postawione pytania, przy jakimkolwiek osłabianiu istotnego dla człowieka związku mężczyzny i kobiety, nie będzie nigdy pełną. A nawet poprawną!

A skoro tak, to ten związek urasta do centralnego problemu teologicznego, wymuszając niejako zajęcie się w tej perspektywie rzeczywistością ludzkiej osoby. Wszystko ze względu na jak najlepsze rozumienie człowieka, w którym - zgodnie z objawioną prawdą o jego stworzeniu - podążamy przez relację mężczyzny do kobiety, stanowiącą ontologiczną podstawę, podniesionego przez Chrystusa do godności sakramentu, małżeństwa. I tu warto sięgnąć do tradycji, która nie zatrzymuje się na szczątkowych danych różnych, zainteresowanych człowiekiem kierunków filozoficznych i nie jest zbyt powierzchowna czy też jednostronna. Chodzi zatem o wyczerpującą, nawet jeśli nierozwiniętą tu w szczegółach, ze względu na charakter tego opracowania, teologiczną wizję ludzkiej osoby, bez pomijania w niej - interesującego nas w tym artykule i zaplanowanego przez Boga odniesienia mężczyzny do kobiety. Innymi słowy próbę gruntownego ujęcia całościowej wizji osoby ludzkiej, zakładającego - ze

\footnotetext{
58 K. Romaniuk, Matżenstwo i rodzina wedtug Biblii, op. cit., s. 205-220.

$59 \quad$ Idem, Krótki zarys historii zbawienia, Warszawa 1987; L. R. Moran, Chrystus w historii zbawienia, Lublin 1994; A. Sarmiento, Matżenstwo chrześcijańskie..., op. cit., s. 69-75.
} 
względu na rzetelność postępowania - rzeczywistość małżeństwa i jego filozoficzną interpretację, otwartą na chrześcijańskie objawienie i refleksję wiary ${ }^{60}$.

Dość przydatne mogą się okazać w tym zamierzeniu rozwiązania włoskiego myśliciela Rocco Buttiglione, ukazującego małżeństwo i rodzinę jako rzeczywistość ludzką par excellence, bez której żadna antropologia nie może być kompletna. Zwłaszcza, kiedy stawia sobie cel dotarcia do pełnej prawdy o człowieku. Stąd, jego zdaniem, wyczerpujące ujęcie związku tego, co „ludzkie” z tym, co „małżeńskie”, można osiągnąć tylko w nurcie personalistycznym, w którym fundamentem poznania filozoficznego jest rzeczywistość ludzkiej osoby. I tu wymiar życia w małżeństwie i rodzinie jest trudny do przecenienia, ponieważ właśnie w tej rzeczywistości, chociażby przez fakt powierzenia się sobie, oddania oraz rodzenia - powołania nowego życia, osoba ukazuje się jako całkowity dar ${ }^{61}$, stanowiąc obraz daru, jakim jest udzielający się w Jezusie Chrystusie człowiekowi Bóg. Poza tym przez ten dar ukazując się jako rzeczywistość obdarowywania i przyjmowania - otwierania się i dawania, dowartościowanego immanentnie, we wspólnocie ludzkiej, przez wewnątrztrynitarne odniesienie w miłości Chrystusa do założonego przez siebie Kościoła. W warunkach doczesności stanowiącej obraz i zarazem podstawę wewnątrzmałżeńskiej relacji, która swoje źródło - z samego faktu bycia człowiekiem - ma w Bogu. W Bogu również, najpełniej objawionemu przez Chrystusa przez całkowity dar z siebie, odnajduje swoje wypełnienie oraz zrozumienie. W tym właśnie sensie należy mówić o pełnej realizacji osoby przez jej otwieranie się na istnienie innej osoby, aby i ona mogła się w pełni rozwijać oraz realizować dzięki drugiemu, wchodzącemu z nią w taką samą relację. Personalizm w tym ujęciu okazuje się wielce pomocny nie tylko dlatego, że dzięki niemu lepiej rozumiemy małżeństwo, ale również dlatego, że przez małżeństwo i rodzinę dzięki temu nurtowi lepiej rozumiemy ludzką osobę. W rodzinie bowiem znajdują swoje miejsce i swoje wyjaśnienie wszystkie istotne aspekty ludzkiej egzystencji, takie jak praca, kultura, życie społeczne, a także śmierć62.

Mówiąc zatem o małżeństwie dotykamy rzeczywistości najbardziej człowiekowi właściwej. Wolno powiedzieć, wymiaru człowieczeństwa w ogóle. Rozumianego jako fundamentalny i tak naprawdę o człowieczeństwie decydujący. W takiej optyce owa szczególna relacja mężczyzny do kobiety nie tylko nie może być przez jakiekolwiek uregulowania prawne tworzona, ale nawet

60 Jan Paweł II, Problem matżeństwa w perspektywie integralnej wizji człowieka (2 IV 1980), [w:] Jan Pawet II o matżeństwie i rodzinie, T. Żeleźnik (red.), Warszawa 1982, s. 158-163.

${ }_{61}$ T. Styczeń, Kościót świata Kościołem rodziny, „Zeszyty Naukowe KUL” 24 (1981) 2-4, s. 5.

62 R. Buttiglione, L'uomo e la famiglia, Roma 1991, s. 13; J. Kłys, Rodzina dziedzictwem ludzkości. Zarys etologii, Szczecin 1995; W. Majkowski, Rodzina w zespole nauk, [w:] Stownik matżenstwa $i$ rodziny, op. cit., s. 398-399. 
przez nie w pełni określana. Powinna za to być wspomagana i zabezpieczona przed marginalizowaniem jej, czy choćby pomniejszaniem. Nie mówiąc nawet o pomijaniu. To samo dotyczy innych czynników: biologicznych, społecznych, kulturowych. Wszystkie składają się na pełny obraz małżeństwa, ale dyskusja na temat jego sakramentalności, wynikających $z$ tego sakramentu skutków, wszystkich konsekwencji, powinna wychodzić z tej podstawy jaką stanowi wymiar osobowy. W ten tylko sposób można wyjaśnić wspólnotę małżeńską i właściwie ją zakorzenić. Każda inna argumentacja okazuje się nieco zewnętrzną, niesięgającą podstaw i niestanowiącą wystarczającej odpowiedzi na pojawiające się kryzysy, w których przecenia się czynniki jurydyczne, biologiczne, społeczne czy kulturowe. I temu właśnie mają służyć nasze rozważania, odwołujące się ze względu na wskazanie Jezusa do „początków”. Oczywiście w Starym Testamencie nie znajdziemy takiej koncepcji osoby ludzkiej, która jest nam dziś znana. Spotykamy jednak bardzo charakterystyczną intuicję, nawet przeświadczenie o wyjątkowości relacji mężczyzny do kobiety, określanej jako podstawowa i przez to trwała, nierozerwalna ( $\mathrm{Rdz} 2,24)$. Stąd potwierdzenia sakramentalności małżeństwa, jej istoty i wszystkiego, co z niej wynika, nie powinno się poszukiwać w jakimś zewnętrznym geście, choćby najbardziej potwierdzonej w historii symbolice religijnej. Jej fundamentem i najgłębszym uzasadnieniem jest relacja, jaka zachodzi między człowiekiem a Bogiem - relacja podobieństwa, która ze względu na objawioną tajemnicę wewnętrznego życia Boga, została już w akcie stworzenia poszerzona o relację w naturze człowieka ${ }^{63}$, czyli we wspólnocie, jaką stanowi mężczyzna i kobieta w communio personarum ${ }^{64}$.

Słowa kluczowe: sakrament, małżeństwo, stworzenie, odkupienie, Wcielenie, misterium paschalne, przymierze, prawo kanoniczne, wspólnota, osoba, personalizm.

\section{Bibliografia:}

1. Arnold B. T., Choi J. H., A Guide to Biblical Hebrew Syntax, Cambridge 2003.

2. Auer J., Die Sakramente der Kirche, Regensburg 1972.

3. Bartnicki R., Poglady na małżeństwo w początkach ery chrześcijańskiej, [w:] Rodzina droga Kościota. Księga Jubileuszowa na 25-lecie postugi pasterskiej Biskupa Łomżyńskiego Stanistawa Stefanka, M. Ozorowski, W. Nowacki (red.), Łomża 2005.

4. Bartnik S. C., Spotkanie personalistyczne, [w:] Ku mądrości teologii, K. Góźdź, E. Sienkiewicz (red.), Szczecin 2008, s. 385-391.

5. Brichto H.Ch., The Names of God, New York 1998.

6. Buttiglione R., L'uomo e la famiglia, Roma 1991.

63 T. Schneider, Znaki bliskości Boga, op. cit., s. 310. 319-322.

64 Jan Paweł II, List do Rodzin, Rzym 1994, 7. 
7. Epos o Gilgameszu, tł. K. Łyczkowska, Warszawa 2002.

8. Franciszek, Evangelii gaudium, Rzym 2013.

9. Garcia López F., Il Pentateuco, Brescia 2004.

10. Grześkowiak J., Centralne idee teologii małżeństwa, [w:] Matżeństwo i rodzina w świetle nauki Kościota $i$ wspótczesnej teologii, A. L. Szafrański (red.), Lublin 1985, s. 19-53.

11. Grześkowiak J., Misterium malżeństwa. Sakrament matżeństwa jako symbol przymierza Boga z ludźmi, Poznań 1993.

12. Jacob B., Das Buch Genesis, Stuttgart 2000.

13. Jagodziński M., Antropologiczno-komunikacyjne podstawy sakramentów, „Studia Diecezji Radomskiej" t. VI, Radom 2004, 247-255.

14. Jan Paweł II, Familiaris consortio, Watykan 1981.

15. Jan Paweł II, List do Rodzin, Rzym 1994.

16. Jan Paweł II, Mężczyzna i niewiasta stworzyt ich. Odkupienie ciała a sakramentalność małżeństwa, T. Styczeń (red.), Lublin 2008.

17. Jan Paweł II, Problem małżenstwa w perspektywie integralnej wizji czlowieka (2 IV 1980), [w:] Jan Pawet II o małżenstwie i rodzinie, T. Żeleźnik (red.), Warszawa 1982, s. 158-163.

18. Jan Paweł II, Zwiazek między pierwotna niewinnościa a odkupieniem dokonanym przez Chrystusa (katecheza z dn. 26.09.1978), [w:] Jan Paweł II, Dzieła zebrane, t. VI, Kraków 2007, s. 97-99.

19. Katechizm Kościoła Katolickiego, Poznań 1994.

20. Kłys J., Rodzina dziedzictwem ludzkości. Zarys etologii, Szczecin 1995.

21. Koch G., Sakramentologia - zbawienie przez sakramenty, t1. W. Szymona, [w:] Podręcznik teologii dogmatycznej, W. Beinert (red.), Kraków 1999.

22. Kodeks Prawa Kanonicznego, przekład polski zatwierdzony przez Konferencję Episkopatu, Poznań 1984.

23. Konferencja Episkopatu Polski, Mszat Rzymski dla diecezji polskich, Warszawa 1986.

24. Kunka S., Teologiczna wizja cielesności czlowieka w nauczaniu Karola Wojtyty - Jana Pawta II, Lublin 2012.

25. Kupczak J., Teologiczna semantyka ptci, Kraków 2013.

26. Lemański J., Księga Rodzaju. Rozdziaty 1-11, [w:] Nowy komentarz biblijny - Stary Testament, A. Paciorek, R. Bartnicki, A. Tronina (red.), Częstochowa 2013.

27. Lubowicki K., Duchowość małżeńska w nauczaniu Jana Pawła II, Kraków 2005.

28. Majkowski W., Rodzina w zespole nauk, [w:] Stownik matżeństwa i rodziny, E. Ozorowski (red.), Warszawa - Łomianki 1999.

29. Moran L. R., Chrystus w historii zbawienia, Lublin 1994.

30. Napiórkowski A. A., Misterium communionis. Eklezjalny paradygmat dziejów zbawienia, Kraków 2006.

31. Necel W., Malzonkowie wzmocnieni i jakby konsekrowani (kan. 1134 KPK). Szkic teologiczno-kanonicznego komentarza w roku synodalnej refleksji nad powotaniem i misją rodziny w Kościele i świecie wspótczesnym, Pelplin 2015.

32. Ozorowski E., Małżenstwo w historii zbawienia, [w:] Stownik matżeństwa i rodziny, E. Ozorowski (red.), Warszawa - Łomianki 1999. 
33. Ozorowski M., Matżenstwo. Przymierze Bosko-ludzkie, [w:] Słownik matżeństwa i rodziny, E. Ozorowski (red.), Warszawa - Łomianki 1999.

34. Pawłowski Z., Opowiadanie, Bóg i poczatek, Teologia narracyjna Rdz 1-3, „Rozprawy i Studia Biblijne” 13, Warszawa 2003.

35. Rahner K., Die Ehe als Sakrament, [w:] Karl Rahner, Schriften zur Theologie, Bd. 8, Einsiedeln - Benziger, 1967.

36. Ratzinger J., Wprowadzenie w chrześcijaństwo, tł. Z. Włodkowa, Kraków 1994.

37. Romaniuk K., Krótki zarys historii zbawienia, Warszawa 1987.

38. Romaniuk K., Małżeństwo i rodzina wedlug Biblii, Warszawa 1994.

39. Sarmiento A., Matżeństwo chrześcijańskie. Podręcznik teologii matżeństwa i rodziny, Kraków 2002.

40. Schneider T., Znaki bliskości Boga. Zarys sakramentologii, tł. J. Tyrawa, Wrocław 1995.

41. Schüle A., Der Prolog der hebräischen Bibel. Der literar und theologiegeschichtliche Diskurs der Urgeschichte (Genesis I - II), Zürich 2006.

42. Ska J.L., La structure du Pentateuque dans sa forme canonique, „Zeitschrift für die alttestamentliche Wissenschaft" 113 (2001), s. 330-352.

43. Skrzypczak R., Kościót jako Niewiasta w relacji do Chrystusa swego Oblubieńca, Warszawa 2001.

44. Stownik matżeństwa i rodziny, E. Ozorowski (red.), Warszawa - Łomianki 1999.

45. Sobór Watykański II, konstytucja dogmatyczna o Kościele Lumen gentium, [w:] Sobór Watykański II, Konstytucje, dekrety, deklaracje, Poznań 1967.

46. Sternberg M., The Poetics of Biblical Narrative. Ideological Literature and the Drama of Reading, Bloomington 1987.

47. Styczeń T., Kościót świata Kościołem rodziny, „Zeszyty Naukowe KUL” 24 (1981) 2-4, s. 3-12.

48. Szczurek J.D., Trójjedyny. Traktat o Bogu w Trójcy Świętej, Kraków 2003.

49. Szymczak J.S., Sakrament małzeństwa drogą wzrostu Kościoła, Łomianki 2001.

50. Testa B., Sakramenty Kościoła, tł. L. Balter, Poznań 1998.

51. The Dictionary of Classical Hebrew, t. 1-6, D. J. A. Clines (red.), Sheffield 1993-2007.

52. Theological Dictionary of the Old Testament, G. J. Botterweck; H. Ringgren, H. J. Fabry (red.), Grand Rapids - Cambridge 1977-2006.

53. Valverde C., Antropologia filozoficzna, Poznań 1998. 